\title{
OCA2 wt Allele
}

National Cancer Institute

\section{Source}

National Cancer Institute. OCA2 wt Allele. NCI Thesaurus. Code C131354.

Human OCA2 wild-type allele is located within 15q12-q13.1 and is approximately $344 \mathrm{~kb}$ in length. This allele, which encodes $\mathrm{P}$ protein, is involved in eye and skin color. Mutations in this gene are associated with type 2 oculocutaneous albinism. 